\title{
GROWTH PERFORMANCE AND ENZYME ACTIVITIES IN CATFISH [Pangasianodon hypophthalmus] FED WITH WATER HYACINTH-BASED DIET
}

\author{
DEWI YUNIATI*, NUR BAMBANG PRIYO UTOMO, MIA SETIAWATI and ALIMUDDIN \\ Department of Aquaculture, Faculty of Fisheries and Marine Science, Institut Pertanian Bogor, \\ Bogor 16680, Indonesia
}

Received 26 April 2017 / Accepted 14 August 2017

\begin{abstract}
An alternative subtitution of pollard as an imported feed ingredient is a neccesity and one of the potential ingredients is water hyacinth (Eichhornia crassipes). This study was conducted to evaluate growth performance and enzyme activity in catfish (Pangasianodon hypophthalmus). Diet with five different levels of water hyacinth subtitute of pollard $(0 \%, 25 \%, 50 \%, 75 \%$, and 100\%) were fed to catfish for 60 days. Seventy (70) catfish fry with average initial body weight of $2.45 \pm 0.15 \mathrm{~g}$ were maintained in $100 \mathrm{~cm} \times 80 \mathrm{~cm} \times 60 \mathrm{~cm}$ aquaria. Fish fed at satiation level three times daily at $8 \mathrm{~mm}, 12 \mathrm{pm}$, and $4 \mathrm{pm}$. With dietary of $25 \%$ water hyacinth, growth performance and protease activity similar to $0 \%$ treatment. Feed intake, protein digestibility, feed efficiency, protein efficiency ratio, and protease and amylase enzyme activities decreased $(\mathrm{p}<0.05)$ in those fed with more than $25 \%$ water hyacinth. Catfish fed $25 \%$ water hyacinth showed significantly $(\mathrm{p}<0.05)$ higher daily growth rate, feed efficiency and protein digestibility than those with other treatments. Based on the growth performance and enzyme activity, we can conclude that the optimum dietary level of water hyacinth subtitute pollard for fry catfish is $25 \%$.
\end{abstract}

Keywords: catfish, growth performance, pollard, water hyacinth

\section{INTRODUCTION}

Feed is the main component to meet the energy needs of the fish. Pollard has a high digestibility and bioavailability as carbohydrate source in fish feed (Suprayudi et al. 2010). Munir et al. (2015) report that pollard contains $53.40 \%$ NFE, $14.78 \%$ protein, $7.77 \%$ lipid, $9.78 \%$ crude fibre, and $4.34 \%$ ash, however an alternative subtitution of pollard as an imported feed ingredient is a neccesity. Research on the use of ingredients of fish feed has been done; Ulva lactuca, Havea brasiliensis, lemna, singgle cell protein (Mahasu 2016; Inara 2011; Bag et al. 2011; Utomo et al. 2007). The research among others, focused on the efforts of using local ingredients and creating efficiency of feed cost. One of the potential ingredients to substitute pollard in fish feed is water hyacinth (Eichhornia crassipes). Water hyacinth has lower cost than pollard, water

\footnotetext{
* Corresponding author: dewiyun25@gmail.com
}

hyacinth cost Rp. 2000/kg while pollard cost Rp. $4800 / \mathrm{kg}$ and changes with time base on the Dollar rate.

Water hyacinth is a South American native plant that has spread to more than 50 countries, including Indonesia. Water hyacinth is one of the aquatic plants that grow in abundance in rivers, rice fields, and lakes or dams. Its characteristics include rapid growth and the ability to compete with other aquatic plants (Shu et al. 2014). Water hyacinth can cover the surface of water bodies, thereby reducing the amount of sunlight and air penetrating into the water. In addition, the plant can cause shallowing and increase evaporation due to evapotranspiration. In a dense population, water hyacinth can impede water flow and block irrigation channels (Sotolu \& Sule 2011). Therefore, the presence of water hyacinth in water bodies is more often regarded as harmful weeds that can negatively impact the aquatic ecosystem (Tellez et al. 2008). 
In previous study, water hyacinth has been used as fish feed in tilapia (Khalil et al. 2015; Bag et al. 2011; Hontiveros et al. 2015; Muchtaromah et al. 2012), Cyprinus carpio (Mohapatra 2015), Clarias gariepinus (Sotolu \& Sule 2011), and Labeo robita (Saha \& Ray 2011). The use of water hyacinth flour as a substitute of fish meal for Clarias gariepinus feed for $26.72 \%$ and $31.63 \%$ showed a lower digestibility rate (Sotolu \& Sule 2011). However, according to Sotolu and Sule (2011), it is still possible to use the plant for fish feed. Hence, water hyacinth was chosen to be the raw material of fish feed in this research. Furthermore, chemical analysis of water hyacinth shows that the plant contains nutrients similar to that of pollard, $30.81 \%$ NFE, $12.40 \%$ protein, $4.72 \%$ lipid with digestibility of water hyacinth leaves reaching up to $76.4 \%$ (Chang et al. 2013; Hontiveros \& Serrano 2015).

The utilization of nutrients in fish feed is closely linked to enzyme activity in fish. The use of different feeds in fish can affect their enzyme activities. Marzuqi (2015) revealed that milkfish given different contents of carbohydrates experience different amylase enzyme activities in line with the increasing contents of carbohydrates in the feed. According to Tibin et al. (2012) the use of water hyacinth indicated a decrease in feed utilization in tilapia fish. There is still gap in knowledge about the use of water hyacinth as a source of plant material in catfish feed. Thus, the present research was carried out to evaluate the use of water hyacinth flour in fish feed as a source of carbohydrate in the growth performance and enzyme activity of catfish Pangasianodon bypophthalmus, an important farmed fish in Southeast Asia.

\section{MATERIALS AND METHODS}

\section{Water Hyacinth Flour}

The water hyacinth flour made from leaves and stems used in this research was taken from the Sukabumi Centre for Freshwater Aquaculture. The water hyacinth was first cleaned and then dried in oven at $60{ }^{\circ} \mathrm{C}$ for 24 hours. The dried water hyacinth was then grinded into flour. Before being used as the ingredient for the feed, a test of heavy metal content was conducted to determine the presence of lead $(\mathrm{Pb})$, cadmium (Cd) and mercury $(\mathrm{Hg})$. The heavy metal content analysis was done using the Atomic Absorption Spectrophotometry method (APHA 2012). The test results showed that no heavy metal contents of lead, cadmium, and mercury were detected in the water hyacinth flour.

\section{Experimental Diets}

The diet containing five different levels of water hyacinth $(0 \%, 25 \%, 50 \%, 75 \%$ and $100 \%)$ as pollard substitute. The premix used were commercial product called Lagantor from Kalbe.

Table 1 Composition and nutrients contained of the experimental diets ( $\% \mathrm{~kg}^{-1}$ dry matter)

\begin{tabular}{crrrrr}
\hline \multirow{2}{*}{ Feed ingredient } & \multicolumn{4}{c}{ Level of pollard subtitution with water hyacinth (\%) } \\
\cline { 2 - 5 } & 0 & 25 & 50 & 75 & 100 \\
\hline Fish meal & 13.00 & 13.00 & 13.00 & 13.00 & 13.00 \\
Meat bone meal & 20.00 & 20.00 & 20.00 & 20.00 & 20.00 \\
Soybean meal & 23.00 & 23.00 & 23.00 & 24.00 & 24.50 \\
Bran & 10.00 & 9.00 & 8.50 & 6.00 & 4.50 \\
Pollard & 25.00 & 18.75 & 12.5 & 6.25 & 0.00 \\
Water Hyacinth Flour & 0.00 & 6.25 & 12.5 & 18.75 & 25.00 \\
Fish Oil & 1.00 & 1.50 & 1.75 & 2.50 & 3.00 \\
Corn Oil & 1.00 & 1.50 & 1.75 & 2.50 & 3.00 \\
Premix & 5.00 & 5.00 & 5.00 & 5.00 & 5.00 \\
Binder (CMC) & 2.00 & 2.00 & 2.00 & 2.00 & 2.00 \\
\hline TOTAL & 100 & 100 & 100 & 100 & 100 \\
\hline Protein & 30.26 & 30.41 & 30.35 & 30.31 & 30.64 \\
Lipid $_{\text {Ash }}$ & 7.28 & 8.33 & 8.56 & 10.07 & 10.75 \\
Fiber & 13.39 & 18.37 & 20.07 & 20.47 & 20.32 \\
NFE & 3.47 & 7.76 & 8.71 & 10.91 & 13.06 \\
GE $^{2}\left(\mathrm{kcal} \mathrm{kg}^{-1}\right)$ & 45.01 & 35.14 & 32.31 & 28.24 & 25.22 \\
\hline Exid & 4243.74 & 3945.85 & 3848.23 & 3821.17 & 3780.40 \\
\hline
\end{tabular}

Note: ${ }^{1}$ Nitrogen Free Extract

${ }^{2}$ Gross Energy, $1 \mathrm{~g}$ protein $=5.6 \mathrm{kcal}, 1 \mathrm{glipid}=9.4 \mathrm{kcal}, 1 \mathrm{~g} \mathrm{NFE}=4.1 \mathrm{kcal}($ Takeuchi 1988$)$. 
The ingredients used were weighed according to their composition and mixed in a mixing machine. After getting evenly mixed, the feed was moulded and heated in the oven at $60^{\circ} \mathrm{C}$ for 4 hours. The composition of the feed and the nutrients contained in it are presented in Table 1.

\section{Fish Rearing}

The catfish Pangasianodon bypopthalmus used originated from Cibanteng, Bogor, Indonesia. The fish were maintained in the Aquatic Laboratory of the Southeast Asian Regional Centre for Tropical Biology (SEAMEO BIOTROP). They were reared in $100 \mathrm{~cm} \times 80 \mathrm{~cm} \times$ $60 \mathrm{~cm}$ aquaria. The aquaria were cleaned and disinfected using $30 \mathrm{ppm}$ chlorine before use. Each of the aquaria was filled with 200L of water. Fish acclimatization was done in two weeks before the rearing period. During the acclimatization, the fish were fed with $50 \%$ treatment feed at satiation level. After acclimatization, the fish were weighed, and the average weight was $2.45 \pm 0.15 \mathrm{~g}$. The fish were then placed randomly into the 15 aquaria with a stocking density of 70 fishes/aquaria.

The rearing of the fish was done for 60 days. Feeding was done at satiation for three times daily at $8 \mathrm{am}, 12 \mathrm{pm}$, and $4 \mathrm{pm}$. The growth was measured by sampling every fifteen days. Every three days $70 \%$ of the water was replaced to maintain the quality of the water during the rearing. Each aquaria was equipped with aeration and heater regulated at $28^{\circ} \mathrm{C}$. The temperature of the water was measured daily, while the water quality was measured three times during the farming process, with parameters including dissolved oxygen, $\mathrm{pH}$, and ammonia. The water quality during farming was at the optimum range for catfish, with a temperature ranging from $28-29^{\circ} \mathrm{C}$, dissolved oxygen of $5.6-6.3 \mathrm{mg} \mathrm{L}^{-1}, \mathrm{pH}$ 7.6-7.8 and ammonia $0.0005-0.02 \mathrm{mg} \mathrm{L}^{-1}$.

At the end of the rearing period, the fish biomass in each of the aquaria was measured. The parameters of survival rate, the amount of feed intake, feed efficiency, and daily growth rate were calculated based on Halver and Hardy (2002); protein efficiency ratio was calculated based on
Webster and Lim (2002); protein and lipid retention were calculated based on Takeuchi (1988). After the final weighing, three pieces of fish were randomly taken from each aquaria for a proximate analysis. Water content analysis was done by drying the sample in an oven at the temperature of $105-110^{\circ} \mathrm{C}$ for 6 hours; analysis of crude fibre was carried out with dissolving method using strong acids and bases and heating; protein analysis with Kjeldahl method, lipid analysis of dried samples with Soxhlet method, lipid analysis of wet samples with Folch method, and ash content analysis by heating sample in a furnace at $600^{\circ} \mathrm{C}$ (Takeuchi 1988).

\section{Enzyme Activity Analysis}

The enzyme activities analysed included those of amylase, protease, and cellulase. The enzyme activities were observed at the end of the experiment. Amylase enzyme activity was measured by the method of Worthington (1993). Cellulase enzyme activity was measured by the method of Kader and Omar (1998). Protease enzyme activity was measured using Bradford's method (Bradford 1976).

\section{Digestibility Test}

The effect of water hyacinth used in feed digestibility was measured using the indirect method by adding chromium oxide $\mathrm{Cr}_{2} \mathrm{O}_{3}$ as an indicator in the feed. Digestibility test was conducted after growth performance tests using the same fish. The fish were fed three times a day at satiation at $8 \mathrm{am}, 12 \mathrm{pm}$, and $4 \mathrm{pm}$. Faecal wastes were first to be collected on the fourth day after giving the feed containing $\mathrm{Cr}_{2} \mathrm{O}_{3}$. The faeces were collected 30 minutes after feeding. The collected faeces from each aquaria were stored in a freezer. The collection of the faeces was done for 25 days. Once collected, the faeces were dried in the oven at $110^{\circ} \mathrm{C}$ for $4-6$ hours. The faeces sample was analysed for its $\mathrm{Cr}_{2} \mathrm{O}_{3}$ and protein contents. The total digestibility value and protein digestibility were calculated using formula of Takeuchi (1988). 


\section{Statistical Analysis}

The design employed in this research was the completely randomized design with five treatments and three replications. Data were analysed using SPSS software ver. 22.0. To find the effects of treatments, data were tested with ANOVA and followed by Duncan test with a 95\% confidence level. The difference between treatments was found with a significance value of $\mathrm{p}<0.05$.

\section{RESULTS AND DISCUSSION}

\section{Growth Performance}

The results showed that the use of water hyacinth of more than $25 \%$ in diet caused a decrease in feed intake, daily growth rate, protein digestibility, protein efficiency ratio, and daily growth rate. Lipid retention and protein retention in the $75 \%$ and $100 \%$ treatments were lower compared to those in other treatments, where in the $100 \%$ treatment, the retention rates were $7.85 \%$ and $19.87 \%$, respectively (Table 2 ).

The use of water hyacinth in fish feed at certain levels gave different results in the feed intake (FI) of the catfish. In this research, the use of more than $25 \%$ water hyacinth in feed caused a decreased in FI. The decreases of FI in the $50 \%$,
$75 \%$ and $100 \%$ treatments compared to $0 \%$ treatment were $11.83 \%, 38.89 \%$, and $45.88 \%$ respectively. In tilapia, the use of water hyacinth in feed did not affect feed consumption, indicating that tilapia could accept feed containing water hyacinth better than Pangasianodon hypopthalmus (Hontiveros et al. 2015). The difference in the feed intake levels in each treatment was assumed to be caused by a difference in the feed palatability. Palatability is a response to certain feed, which is influenced, among others, by feed characteristics. In addition, the acceptance of fish to raw material is different for each species (Setiawati et al. 2014). Venero et al. (2008) mentioned that the use of plant materials can reduce feed acceptability and feed palatability. Palatability is linked to attractability that will influence responses in feed searching, intake, and ingestion or acceptability (Inara 2011). The decreased rate of FI was followed by a decreased in digestibility rate. Digestibility is the process of breaking down feed into a simpler form that is readily absorbed by intestinal walls and into the blood vessel system. There was no difference in the total digestibility of feed in all treatments $(p>0.05)$. This is in contrast to protein digestibility that experienced a decrease in line with the increasing amount of water hyacinth in feed $(p<0.05)$. Diet containing $0 \%$ and $25 \%$ water hyacinth showed similiar result of $82 \%$, whilst in

Tabel 2 Final biomass (Bt), feed intake (FI), total digestibility (TD), protein digestibility (PD), protein retention (PR), lipid retention (LR), protein efficiency ratio (PER), daily growth rate (DGR), feed efficiency (FE), survival rate (SR) of catfish (Pangasianodon hypophthalmus) fed with feed containing water hyacinth

\begin{tabular}{|c|c|c|c|c|c|}
\hline \multirow{2}{*}{ Parameter } & \multicolumn{5}{|c|}{ Treatments of water hyacinth flour substitution } \\
\hline & $0 \%$ & $25 \%$ & $50 \%$ & $75 \%$ & $100 \%$ \\
\hline $\mathrm{Bt}_{60}(\mathrm{~g})$ & $563.39 \pm 3.69^{\mathrm{a}}$ & $558.33 \pm 4.82^{\mathrm{a}}$ & $408.17 \pm 3.89^{\mathrm{b}}$ & $262.83 \pm 1.68^{c}$ & $239.62 \pm 5.24^{\mathrm{d}}$ \\
\hline $\mathrm{FI}(\mathrm{g})$ & $599.26 \pm 8.23^{\mathrm{a}}$ & $585.62 \pm 11.88^{\mathrm{a}}$ & $528.35 \pm 6.94^{b}$ & $366.21 \pm 5.38^{c}$ & $324.31 \pm 10.61^{\mathrm{d}}$ \\
\hline TD $(\%)$ & $41.19 \pm 0.58^{\mathrm{a}}$ & $41.26 \pm 5.47^{\mathrm{a}}$ & $42.07 \pm 6.39^{a}$ & $41.03 \pm 2.13^{\mathrm{a}}$ & $42.91 \pm 0.14^{\mathrm{a}}$ \\
\hline PD (\%) & $82.09 \pm 0.21^{\mathrm{a}}$ & $82.56 \pm 1.50^{\mathrm{a}}$ & $79.92 \pm 1.43^{b}$ & $74.57 \pm 1.31^{\mathrm{c}}$ & $75.96 \pm 0.49^{c}$ \\
\hline PER & $2.30 \pm 0.07^{\mathrm{a}}$ & $2.37 \pm 0.03^{\mathrm{a}}$ & $1.63 \pm 0.04^{b}$ & $0.96 \pm 0.06^{c}$ & $0.81 \pm 0.06^{\mathrm{d}}$ \\
\hline PR $(\%)$ & $27.30 \pm 4.37^{\mathrm{a}}$ & $25.93 \pm 1.36^{\mathrm{a}}$ & $22.02 \pm 7.84^{a}$ & $7.79 \pm 2.51^{b}$ & $7.83 \pm 5.19^{\mathrm{b}}$ \\
\hline LR $(\%)$ & $47.46 \pm 7.68^{\mathrm{a}}$ & $46.54 \pm 1.67 \mathrm{a}$ & $40.93 \pm 6.84^{a}$ & $18.35 \pm 6.79^{\mathrm{b}}$ & $19.67 \pm 1.37 \mathrm{~b}$ \\
\hline DGR $\left(\%\right.$ day $\left.^{-1}\right)$ & $2.03 \pm 0.07^{a}$ & $2.03 \pm 0.03^{\mathrm{a}}$ & $1.48 \pm 1.11^{b}$ & $0.75 \pm 0.03^{c}$ & $0.61 \pm 0.03^{\mathrm{d}}$ \\
\hline $\mathrm{FE}(\%)$ & $65.69 \pm 1.95^{\mathrm{a}}$ & $67.01 \pm 0.85^{\mathrm{a}}$ & $45.42 \pm 1.31^{b}$ & $27.00 \pm 1.75^{c}$ & $22.81 \pm 1.45^{\mathrm{d}}$ \\
\hline SR $(\%)$ & $98.10 \pm 3.30^{\mathrm{a}}$ & $97.62 \pm 0.82^{\mathrm{a}}$ & $98.57 \pm 1.43^{\mathrm{a}}$ & $97.62 \pm 2.18^{\mathrm{a}}$ & $97.14 \pm 3.78^{a}$ \\
\hline
\end{tabular}

Note: $\left.{ }^{*}\right)$ The values in the same rows with different superscript letters indicate significant differences $(p<0.05)$. 
the $50 \%, 75 \%$, and $100 \%$ treatments, it decreased to $79.92 \%, 74.57 \%$, and $75.96 \%$ respectively. The factors affecting digestibility are, among others, the treatments before and after feed making, material sources, particle size, fish size, and nonprotein components in the feed (Usman 2002). The decrease in protein digestibility value of 50 $100 \%$ treatment in this study were caused by the increasing amount of crude fibre that can disturb feed utilization and growth. Mohapatra (2015) reports that the use of water hyacinth significantly increases the crude fibre and affects the feed utilization of Cyprinus. In the current study, the crude fibre content of $0-100 \%$ treatments were at the range of $3.47-13.06 \%$. The higher the fibre content in the feed, the lower digestibility of protein. This result is in accordance with the report of Suprayudi et al. (2010).

The end products of the consumed and digested feed are nutrients that can be used and then stored in the fish body. The levels of protein and lipid retentions in the $0-50 \%$ treatments were the same, and they declined in the $75 \%$ and $100 \%$ treatments. The different protein and lipid retention levels were caused by differences in the amount of feed intake and feed digestibility value. Carbohydrate, protein, and lipid are the three components that contribute the highest amount of energy for the fish. If low amounts of nutrients are absorbed, their potential to be stored in the fish will also be low, because the nutrients will be first used for the fish activities. This also applies to growth: if a small amount of energy is received by the fish, then the energy for its growth will be even much less. The use of certain levels of water hyacinth in feed gave positive effect on the growth of Cyprinus (Mohapatra 2015). In this research, the use of more than $25 \%$ water hyacinth negatively impacted the growth of the catfish. Compared to $0 \%$ treatment, the percentages of daily growth in the $50 \%, 75 \%$ and $100 \%$ treatments decreased. The decreased of daily growth in the $50 \%, 75 \%$, and $100 \%$ treatments were $27.1 \%$ day $^{-1}, 55.6 \%$ day ${ }^{1}$, and $69.9 \% \mathrm{day}^{-1}$, respectively. The lowering growth rate in the fish can be attributed to the unfulfilled needs of nutrients in the fish and the inability of the fish to use the energy and materials in their feed (Usman 2002). Feed intake in the $0 \%$ and $25 \%$ treatments were better than that in the other treatments, hence the amount of the ingested feed was greater in the $0 \%$ and $25 \%$ treatments. The difference presumably caused more energy to be received in $0 \%$ and $25 \%$ treatments, resulting in better growth. In this research, the crude fibre content in the feed increased along with the increasing proportion of water hyacinth flour in the feed. The crude fibre derived from vegetable materials is in general difficult to be digested by fish. In addition, one of the components of cell walls in plants is cellulose that is intractable (Inara 2011). The better growth in the $0 \%$ and $25 \%$ treatments reflects feed efficiency value. This value indicates that the antinutritional substances and the high fibre content in the $0 \%$ and $25 \%$ treatments did not disturb the use of feed by the catfish. The survival rate ranged from $97.14-98.57 \%$, indicating that water hyacinth did have any harmful effects on the fish.

\section{Enzymes Activities}

Similar protease enzyme activities were found in the $0 \%$ and $25 \%$ treatments, thus have different result compared to the $50 \%-100 \%$ treatments (Fig. 1). Similar cellulase enzyme activities were found in all treatments (Fig. 2). Different amylase enzyme activities were observed in all treatment (Fig. 3).

Enzymes have an important role in digestion process. The protease enzyme activities in the $0 \%$ and $25 \%$ treatments were greater than those in the $50-100 \%$ treatments. The declining protease enzyme activities in the 50-100\% treatments were assumed to be caused by the anti-nutritional substances in the feed. Water hyacinth contains anti-nutritional substances such as tannin and phytic acid of $0.98 \%$ and $0.42 \%$, respectively. Anti-nutritional substances such as tannin can affect growth and enzyme profiles of fish. Tannin impedes protease enzyme activity and therefore can reduce protein digestibility, while phytic acid can reduce protein and mineral bioavailability (Saha \& Ray 2011). In addition, the declining enzyme activities can also be caused by the amount of the substrates present in the feed intake. In this study, fish fed diet containing $50-100 \%$ water hyacinth showed lower feed intake than those fed with $0 \%$ and $25 \%$ water hyacinth, which was directly proportional to the amount of substrates for the enzyme in their digestive systems. The higher feed intake and protein digestibility in the $0 \%$ and $25 \%$ treatments compared to those in other treatments had an impact on the high value of protein 


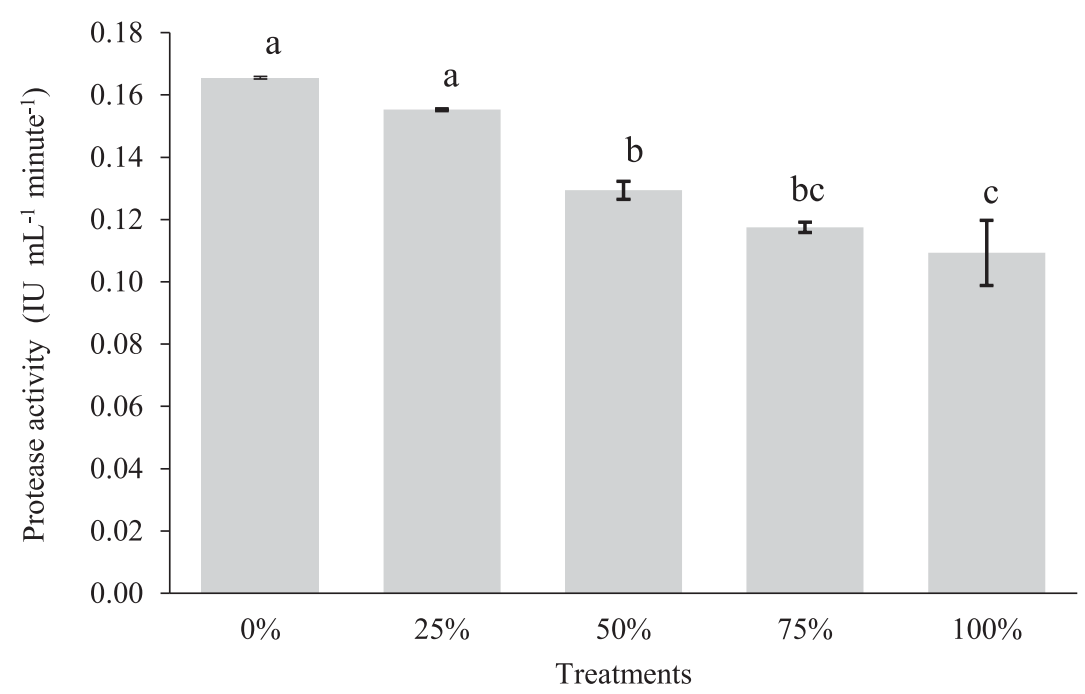

Figure 1 Protease enzyme activities in catfish fed with feed containing different levels of water hyacinth

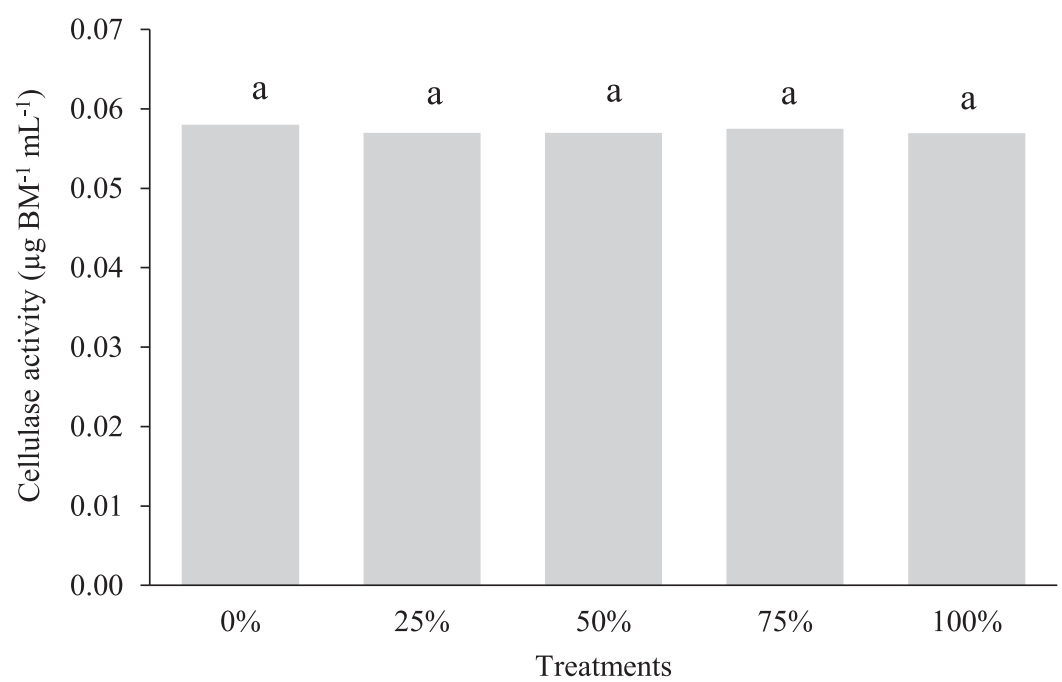

Figure 2 Cellulase enzyme activities in catfish fed with feed containing different levels of water hyacinth

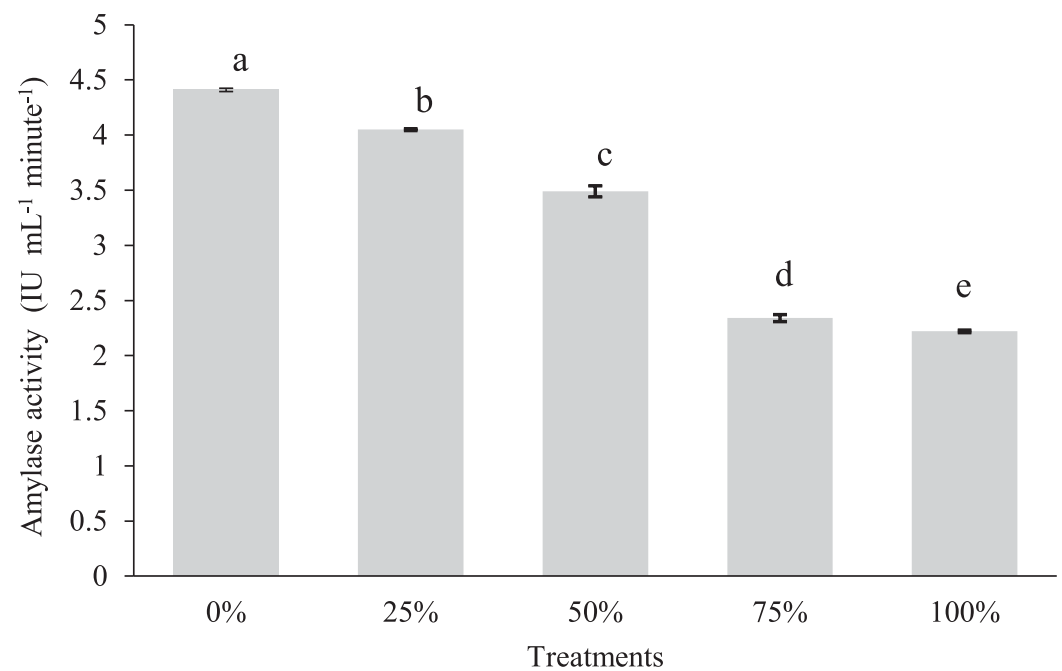

Figure 3 Amylase enzyme activities in catfish fed with feed containing different levels of water hyacinth 
efficiency ratio in these treatments, namely 2.30 and 2.37 , respectively.

The cellulase enzyme activities observed were not different in all treatments. This is attributed to the low amount of cellulase enzyme in the fish that worked maximally in all treatments, although there were differences in the amounts of feed intake and water hyacinth in each feed. The amylase enzyme activities were found to be different in all treatments. The amylase enzyme activities in the $50-100 \%$ treatments were lower than those in other treatments. Amylase enzymes break down starch in feed. The amylase enzyme activites decreased with increasing level of water hyacinth assumed to be caused by the low carbohydrate content as the level of water hyacinth increased.

\section{CONCLUSION}

The Pangasianodon bypopthalmus fed diet containing $25 \%$ water hyacinth subtitute pollard showed similar growth performance and protease activity with $0 \%$ treatment. The use of water hyacinth of more than $25 \%$ showed lower growth performance than other treatments. Water hyacinth flour can be used for up to $25 \%$ or $6.25 \%$ in the diet of Pangasianodon hypopthalmus.

\section{ACKNOWLEDGEMENTS}

We would like to express our gratitude to the Southeast Asian Regional Centre for Tropical Biology (SEAMEO BIOTROP) for the opportunity to conduct our research in its Aquatic Laboratory, and our gratitude also goes to the Centre for Freshwater Aquaculture, Sukabumi, for providing water hyacinth flour for the study.

\section{REFERENCES}

American Public Health Association (APHA). 2012. Standard method for examination of water and wastewater, 22th edition. Washington DC (US): American Water Works Association and Water Pollution Control Federation.

Bag MP, Mahapatra SC, Rao PS, Chakrabarty D. 2011. Making aquatic weed as potential feed for nile tilapia Oreochrmis niloticus $\mathrm{L}$. and its impact on fatty acid profile. IRJPP 1(8):194-202.
Bradford MM. 1976. A rapid and sensitive for the quantitation of microgram quantities of protein utilizing the principle of protein-dye binding. Anal Biochem 72(1-2):248-54.

Chang CC, Tan HC, Cheng W. 2013. Effects of dietary administration of water hyacinth Eichhornia crassipes extract on the immune responses and disease resistance of giant freshwater prawn, Macrobrachium rosenbergii. Fish Shellfish Immunol 35(1):92-100.

Halver JE, Hardy RW. 2002. Fish nutrition. California (US): Academic Press. p. 50.

Hontiveros GJS, Serrano AEJ. 2015. Nutritional value of water hyacinth Eichhornia crassipes leaf protein concentrate for aquafeeds. AACL Bioflux $8(1): 26-33$.

Hontiveros GJS, Tumbokon BLM, Serrano AEJ. 2015. Protein concentrate of water hyacinth partially replace soybean meal in the diet of the Nile tilapia Oreochromis niloticus juveniles. ABAH Bioflux 7(1):60-6.

Inara C. 2011. Kajian tepung bungkil biji karet (TBBK) Heavea brasiliensis sebagai bahan baku pakan benih ikan mas Cyprinus carpio Linn [Thesis]. [Study of rubber seed flour (TBBK) Heavea brasiliensis as feed raw material for carp Cyprinus carpio Linn juvenile]. Retrieved from Bogor Agricultural University Repository.

Kader AJ, Omar O. 1998. Isolation of cellulolytic fungi from Sayap-Kinabalu Park, Sabah, Serawak. J Biodiversity Bio-Century (ARBEC) 2:1-6.

Khalil M, Maulana R, Rusydi R. 2015. Efektifitas beberapa jenis tanaman air sebagai pakan alami terhadap pertumbuhan benih ikan nila gesit Oreochromis niloticus. TThe effectiveness of several types of aquatic plants as natural diet for the growth of nimble tilapia Oreochromis niloticus fish juvenile]. Jurnal Samudera 9(2):90-102.

Mahasu NH. 2016. Evaluasi penggunaan rumput laut Ulva lactuca sebagai pengganti pollard dalam pakan ikan nila sultana Oreochromis niloticus [Thesis]. [Evaluation of the use of seaweed Ulva lactuca as a substitute for pollard in feeding tilapia sultana Oreochromis niloticus]. Retrieved from Bogor Agricultural University Repository.

Marzuqi M. 2015. Pengaruh kadar karbohidrat dalam pakan terhadap pertumbuhan, efisiensi pakan dan aktivitas enzim amilase pada ikan bandeng Chanos chanos Forsskal [Thesis]. [Effect of carbohydrate levels in diet on growth, feed efficiency and amylase enzyme activity of milkfish Chanos chanos Forsskal]. Retrieved from Udayana University Repository.

Mohapatra SB. 2015. Utilization of water hyacinth Eichhornia crassipes meal as partial fish protein replacement in the diet of Cyprinus carpio fry. Euro J Exp Bio 5(5):31-36. 
Muchtaromah B, Susilowati R, Kusumastuti A. 2012. Pemanfaatan tepung hasil fermentasi eceng gondok Eichhornia crassipes sebagai campuran pakan ikan untuk meningkatkan berat badan dan daya cerna protein ikan nila merah Oreochromis sp. [Utilization of Eichhornia crassipes water hyacinth fermented flour as a fish diet mixture to increase weight and protein digestibility of red tilapia Oreochromis sp.]. Jurnal ElQudwah 10:1-9.

Munir M, Sidik R, Mahasri G. 2015. Peningkatan nilai nutrisi pollard melalui fermentasi ragi tempe sebagai bahan pakan buatan ikan nila Oreochromis niloticus. Increasing the value of pollard nutrients through fermentation of tempe yeast as an ingredient for artificial diet of tilapia Oreochromis niloticus]. Jurnal Ilmiah Perikanan dan Kelautan 7:67-70.

Saha S, Ray AK. 2011. Evaluation of nutritive value of water hyacinth Eichhornia crassipes leaf meal in compound diets for rohu, Labeo robita (Hamilton, 1822) fingerlings after fermentation with two bacterial strains isolated from fish gut. Turk J Fish Aquat Sci 11:199-207.

Setiawati M, Jusadi D, Marlinda S, Syafruddin D. 2014. Pemberian daun kayu manis Cinnamomum burmanni dalam pakan terhadap kinerja pertumbuhan dan komposisi nutrien tubuh ikan patin Pangasius bypopthalmus. [Effect of addition Cinnamomun Burmanni leaf in the diet on the growth performance and nutrient composition of Pangasius hypopthalmus]. JIPI 19(2):80-84.

Shu X, Zhang Q, Wang W. 2014. Effects of temperature and light intensity on growth and physiology in purple root water hyacinth and common water hyacinth Eichhornia crassipes. Environ Sci Pollut Res 21(22):12979-88.

Sotolu AO, Sule SO. 2011. Digestibility and performance of water hyacinth meal in the diets of African catfish Clarias gariepinus; Burchell, 1822. Trop Subtrop Agroecosyst 14:245-50.

Suprayudi M, Yaniharto D, Ridwan. 2010. Penggunaan kombinasi kadar karbohidrat berbeda dari tepung tapioka, jagung dan pollard terhadap kinerja pertumbuhan juvenil larva udang windu Penaeus monodon. [The utilization of different combination and level of corn, tapioca and pollard on the growth performance of black tiger shrimp (Penaeus monodon) juvenile]. Jurnal Akuakultur Indonesia 9:104-9.

Takeuchi T. 1988. Laboratory work-chemical evaluation of dietary nutrients. In: Watanabe T, editor. Fish Nutrition and Mariculture, JICA Textbook, the General Aquaculture Course. Tokyo (JP): Kanagawa International Fish Training Center.

Tellez TR, Lopez EM, Granado GL, Perez EA, Lopez RM, Guzman MS. 2008. The water hyacinth, Eichbornia crassipes: An invasive plant in the Guardiana River Basin (Spain). Aquat Invasions 3(1):42-53.

Tibin A, Munafi A, Amiza AM, Bakhsh HK, Sulieman A. 2012. Apparent digestibility coefficient of pelleted fish feed incorporated with water hyacinth Eichhornia crassipes. OJAFR 2(1):30-3.

Usman 2002. Pengaruh jenis karbohidrat terhadap kecernaan nutrien pakan, kadar glukosa darah, efisiensi pakan dan pertumbuhan yuwana ikan kerapu tikus Cromileptes altivelis [Thesis]. [Effect of carbohydrate types on nutrient digestibility of feed, blood glucose levels, feed efficiency and growth of yuwana humpback grouper Cromileptes altivelis]. Retrieved from Bogor Agricutural University Repository.

Utomo NBP, Mokoginta I, Suwendi E. 2007. Protein sel tunggal sebagai substitusi tepung ikan dalam pakan juvenil ikan mas (Cyprinus carpio). [Single cell protein as substitution for fish meal in juvenile common carp (Cyprinus carpio) diets]. Jurnal Perikanan 9(2):188-93.

Venero JA, Davis DA, Lin C. 2008. Use of plant protein sources in crustacean diets. New York (US): The Howort Press. p. 163-203.

Webster CD, Lim CE. 2002. Nutrient requirements and feeding of finfish for aquaculture. New York (US): CABI Publishing. p. 4-5.

Worthington V. 1993. Worthington enzyme manual. New Jersey (US): Worthington biochemical Corporation. 